\title{
ENDOCHRONIC MODEL OF PLASTICITY GENERALIZING SANDERS'S THEORY
}

\begin{abstract}
The Sanders's theory of plasticity and quasi-statistical variant of incremental plastic theory with isotropic and kinematic hardening in Novozhilov's version are generalized in the frameworks of the endochronic approach. The constitutive equations of endochronic theory of inelasticity including the ideas of Sanders, Novozhilov and Valanis are formulated. The relations for the calculation of stresses and strains in uniaxial active and reversible material loadings are proposed. The formulas are obtained by using the elementary average principle of local values and by the simplest set of material constants and functions. Two types of initial conditions are considered in the calculations. The results of numerical modeling of inelastic material behavior under uniaxial active and cyclic loadings are presented. The results are compared with each other and with original Sanders's theory. The similarity and differences between the generalized endochronic theory and the Sanders's version are demonstrated. Several unusual manifestations of inelastic material behavior that require further theoretical analysis, calculations on the complex loading paths and the experimental verification are noted.
\end{abstract}

Keywords: plasticity, theory, endochronic approach, constitutive equations, quasi-statistical variant

\section{Introduction}

The new approach to the formulation of theory of plasticity was presented by Sanders in 1955 [1]. In its foundations the new theory used the set of the plane closed piecewise-linear yield surfaces and the macroscopic yield surface was interpreted as the envelope of local ones. The Sanders's approach was promoted actively by Klyushnikov [2]. It was found [2] that the potentialities of Sanders's theory were similar to capabilities of deformation theory [3] and the conception of slip in Batdorf-Budiansky's form [4]. The similarities of results of

\footnotetext{
${ }^{1}$ Yulij Kadashevich, Technological University of Plant Polymers, e-mail: kadashevichyulij@yandex.ru

2 Autor do korespondencji/corresponding author: Sergey Pomytkin, University of Aerospace Instrumentation, 67 Bolshaya Morskaia St., Saint-Petersburg 190000, Russia, tel.: (+7 812) 7084372, e-mail: sppom@yandex.ru
} 
the Sanders's constitutive equations and Batdorf-Budiansky's theory were noticed by Bazant [5] for soils and concretes. The original multi-surfaces theory of plasticity by using the movement of smooth surfaces was proposed by Mroz [6].

The limit quasi-statistical variant of Sanders's theory accounting initial microstresses was published by Kadashevich and Novozhilov [7]. In 1971 the original endochronic theory was proposed by Valanis $[8,9]$. The active development of endochronic theories began after that [5, 10-13]. Today the endochronic approach is the generally accepted method in researches on the inelastic behavior of materials. There were some studies related to the endochronic theory with the famous classical ones: deformation theory [10], concept of slip [5], incremental theory [5, 14], etc.

In this paper the formulation of the endochronic constitutive equations generalizing the Sanders's plastic theory [1], the statistical approach for the incremental plasticity [7] and endochronic ideas [15] is proposed. Quasi-statistical equations of the new theory are based on the movement of independent piecewise linear planar yield surfaces [7] and on technology of conversion from incremental plasticity to endochronic theory [14].

\section{New proposals}

As the base the quasi-statistical limit variant of Sanders's theory taking into account the initial microstresses is considered [7]. It is supposed [7] that the first and the third invariants of stress tensor do not influence the process of plastic deformation. Also it is postulated that local yield surfaces remain the planar piecewise linear and move independently in Ilyushin's space [3]. Each surface begins the motion when the stress point comes up to its boundary. Constitutive equations of that theory can be formulated in the form [7]:

$$
\begin{aligned}
& \sum_{k=1}^{5}\left(\sigma_{k}-b \varepsilon_{k}^{p}\right) \cdot \cos \varphi_{k}=\tau, \quad \varepsilon_{k}^{p}=\varepsilon_{i}^{p} \cdot \cos \varphi_{k} \\
& \sum_{k=1}^{5} \cos ^{2} \varphi_{k}=1, \quad \sigma_{k}=<\sigma_{k}>, \quad<\varepsilon_{k}^{e}>=<\sigma_{k}>/ 2 G \\
& <\varepsilon_{k}^{p}>=\frac{1}{2 \pi} \int_{-\varphi_{0}}^{+\varphi_{0}} \varepsilon_{k}^{p} \mathrm{~d} \varphi, \quad<\varepsilon_{k}>=<\varepsilon_{k}^{e}>+<\varepsilon_{k}^{p}>
\end{aligned}
$$

Here $\sigma_{k}, \varepsilon_{k}^{p}, \varepsilon_{k}^{e}$ are the components of stresses, plastic and elastic strains in vector Ilyushin's space; $\varepsilon_{i}^{p}$ is the effective plastic strain rate, $\varepsilon_{i}^{p}=\left(\varepsilon_{k}^{p} \cdot \varepsilon_{k}^{p}\right)^{1 / 2} ; \tau$ is the yield limit; $b$ is a constant material parameter; $G$ is 
the shear modulus; $\langle\ldots\rangle$ is the mean value of any magnitude; $\varphi_{0}$ is the limit value of angle $\varphi$ when the planes of the yield surfaces can not move. (The motion of the yield surfaces is fulfilled in the range $-\varphi_{0} \leq \varphi \leq \varphi_{0}$ only).

Particularly, for uniaxial loading it was found [7] that:

$$
\begin{aligned}
& b \varepsilon_{1}^{p}=\sigma_{1} \cos ^{2} \varphi-\tau \cdot \cos \varphi, \quad \sigma_{1} \cos \varphi_{0}=\tau \\
& \left\langle\varepsilon_{1}^{e}\right\rangle=\frac{\sigma_{1}}{2 G} \text { and }\left\langle\varepsilon_{1}^{p}\right\rangle=0, \text { if } \sigma_{1}<\tau \\
& \left\langle\varepsilon_{1}^{e}\right\rangle=\frac{\tau}{2 G \cdot \cos \varphi_{0}}, \text { if } \sigma_{1} \geq \tau \\
& \left\langle\varepsilon_{1}^{p}\right\rangle=\frac{\tau}{2 \pi b}\left(\frac{\varphi_{0}}{\cos \varphi_{0}}-\sin \varphi_{0}\right) \\
& \left.\left.\left\langle\varepsilon_{1}\right\rangle=<\varepsilon_{1}^{e}\right\rangle+<\varepsilon_{1}^{p}\right\rangle
\end{aligned}
$$

Asymptotic behavior of solution (4), (6) is:

$$
\left\langle\varepsilon_{1}^{p}\right\rangle=\frac{1}{4 b}\left(\sigma_{1}-\frac{4 \tau}{\pi}\right) .
$$

Based on the idea of Valanis about intrinsic time measure [15] the endochronic variant of relations (1)-(3) is proposed now. The new vector $b r_{k}$ is introduced in place of vector $b \varepsilon_{k}^{p}$ according to formula:

$$
r_{k}=\varepsilon_{k}-\frac{1-\alpha}{2 G} \sigma_{k}
$$

The definition (8) contains the endochronic parameter $\alpha$ and $0 \leq \alpha \leq 1$. Then we can write that:

$$
\begin{aligned}
& \sum_{k=1}^{5}\left(\sigma_{k}-b r_{k}\right) \cdot \cos \varphi_{k}=\tau, \quad r_{k}=r_{i} \cdot \cos \varphi_{k} \\
& b r_{i}=\sum_{k=1}^{5} \sigma_{k} \cdot \cos \varphi_{k}-\tau, \quad r_{i}=\left(r_{k} \cdot r_{k}\right)^{1 / 2}
\end{aligned}
$$




$$
\sum_{k=1}^{5} \cos ^{2} \varphi_{k}=1
$$

As in the classical theory of endochronic type [15] three partial cases of the relations (8)-(10) are interesting:

a) if $\alpha=0$, then $r_{k}=\varepsilon_{k}^{p}$ and we have the various variants of incremental theory of plasticity,

b) if $\alpha=1$, then $r_{k}=\varepsilon_{k}$ and we have one of the limit variant of Valanis's theory $[8,9]$,

c) if $\alpha \rightarrow 0$, then the solutions a) and b) can be differed essentially (under the cycling loading especially).

Additionally it should be noted that the strains are not separated into the elastic and the plastic parts in endochronic approaches when $\alpha \geq 0$.

In endochronic theory [15] the constitutive equations contain the small term $\alpha \dot{\sigma}$ for the guarantee of initial conditions as $\varepsilon=0, \sigma=0$. In present variant of theory (8)-(10) the condition:

$$
\sigma_{1}=\frac{\tau}{\cos \varphi_{0}} \cdot\left(1-\cos \varphi_{0}\right)
$$

is used in return for (4). Obviously that if $\phi_{0}=0$ then $\sigma_{1}=0$. From (11) we have concluded that $r_{i}$ is taken actually as:

$$
b r_{i}=\sum_{k=1}^{5}\left(\sigma_{k}+\tau\right) \cdot \cos \varphi_{k}-\tau
$$

for provision of correctness of the equations from initial value $\phi=0$.

For uniaxial loading we have:

$$
b r_{1}=\left[\left(\sigma_{1}+\tau\right) \cdot \cos \varphi-\tau\right] \cdot \cos \varphi
$$

In the case of $\alpha=1$ the mean value of strain is:

$$
\left\langle\varepsilon_{1}\right\rangle=\frac{\tau}{2 \pi b}\left(\frac{1+\varphi_{0}-\sin \varphi_{0} \cdot \cos \varphi_{0}}{\cos \varphi_{0}}-1\right)
$$

Using the formulas (11), (13) and the averaging as:

$$
<r_{1}>=\frac{1}{2 \pi b} \int_{-\varphi_{0}}^{+\varphi_{0}} r_{1} \mathrm{~d} \varphi
$$


can be established also that

$$
\left\langle r_{1}\right\rangle=\frac{\tau}{2 \pi b}\left(\frac{\varphi_{0}}{\cos \varphi_{0}}-\sin \varphi_{0}\right)
$$

\section{Numerical modeling and results}

To demonstrate some features of the new endochronic version of the Sanders's theory the numerical simulations of inelastic material behavior under uniaxial loading and cyclic loadings were made. The solutions for uniaxial tension are presented in fig. 1.:

- the graph a) is based on the theory of Sanders [1], the formulas (4)-(7),

- the diagram b) is the result of using the endochronic variant in the form (11) and (14),

- the curve c) is the consequence from the endochronic formulae (11) and (16).

The solutions for uniaxial cyclic loading according to the scheme of Sanders, by formulas (11), (14), (17) and by the methods (11) and (16) are shown in figs. 2-4, respectively. In this modeling the forward tension $\sigma_{1}$ up to value $\sigma_{1}=\sigma_{1}^{0}$ then changes the direction to the opposite. Symbol $\varepsilon_{1}^{0}$ denotes the strain when the stress is equal to $\sigma_{1}^{0}$. It should be noted that according to the ideas of Sanders [1] the plastic strains in forward-reverse loading are generated by other planar yield surfaces located in range of values from $-\pi+\phi$ to $\pi+\phi$. In all calculations it was accepted when $\varphi_{0} \geq 0, \alpha=1,2 G=1, \tau=1$ and $2 \pi b=1$, i.e. the material was taken as hypothetical.

Using the relations (11) and (14) the solution of uniaxial forward-reverse loading can be obtained in the form of:

$$
\begin{aligned}
& \sigma_{1}=\sigma_{1}^{0}+\frac{\tau}{\cos \varphi_{0}} \cdot\left(\cos \varphi_{0}-1\right), \text { if } \varphi_{0} \geq 0 \\
& \varepsilon_{1}=\varepsilon_{1}^{0}+\frac{\tau}{2 \pi b} \cdot\left(1+\frac{\sin \varphi_{0} \cdot \cos \varphi_{0}-\varphi_{0}-1}{\cos \varphi_{0}}\right), \text { if } \varphi_{0} \geq 0
\end{aligned}
$$

In the figure 1 . the line a) corresponds to the diagrams of elastic-linearhardening materials and the graphs b) and c) are weakly nonlinear as a consequence of the selected parameters for calculations. But the cyclic „stress-strain” curves in the figs. 2-4 may be challenged by experimenters. However, they are presented here deliberately to emphasize the specific approach of Sanders and need further development of the method proposed above. 


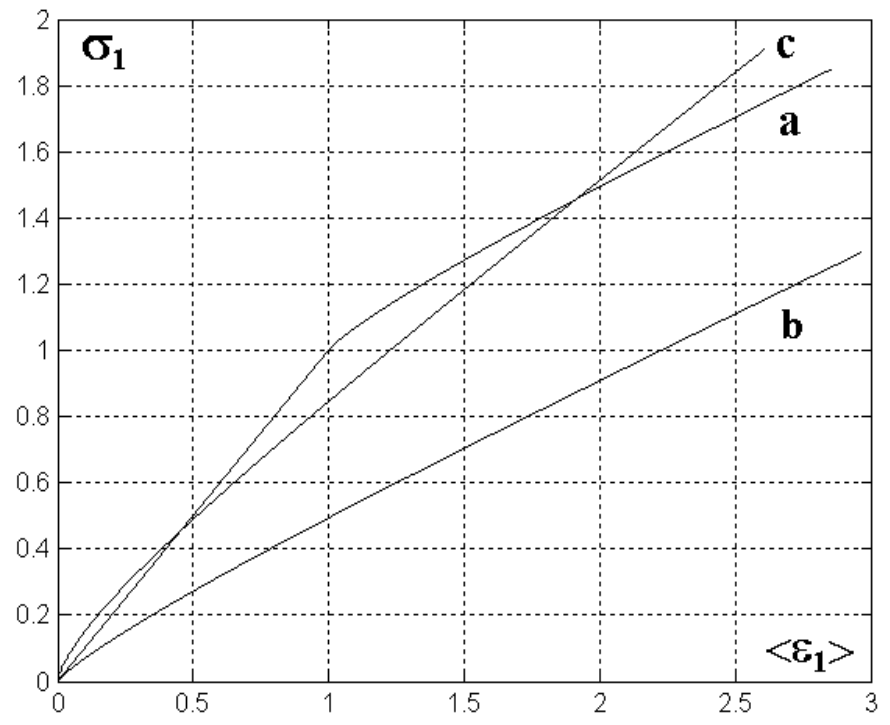

Fig. 1. Stress-strain curves under uniaxial loading: a-c - explanation in text

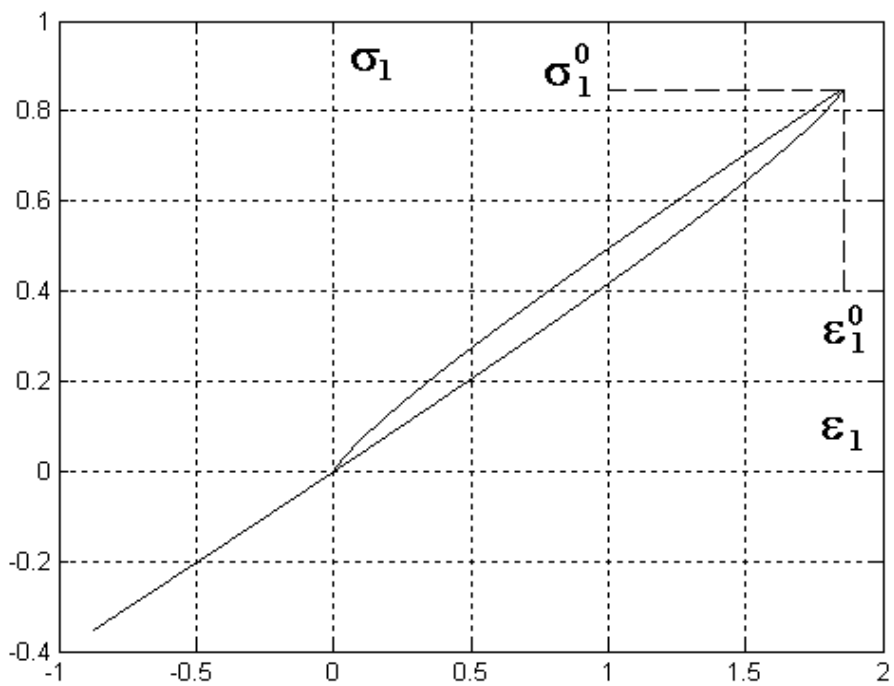

Fig. 2. Cyclic uniaxial loading on outlines of Sanders 


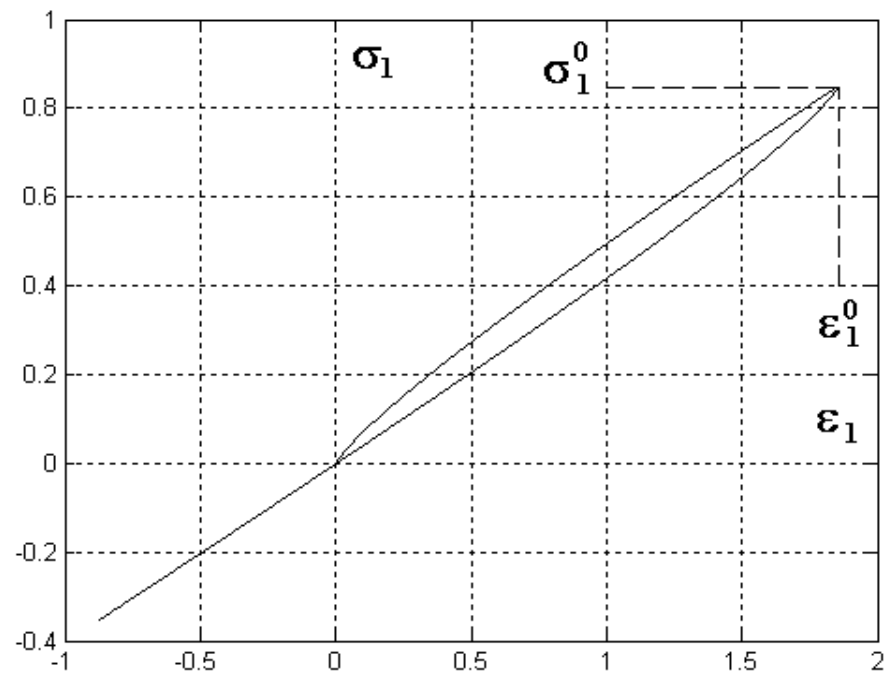

Fig. 3. Uniaxial forward-reverse deformation according to eqs. (11), (14), (17) and (18)

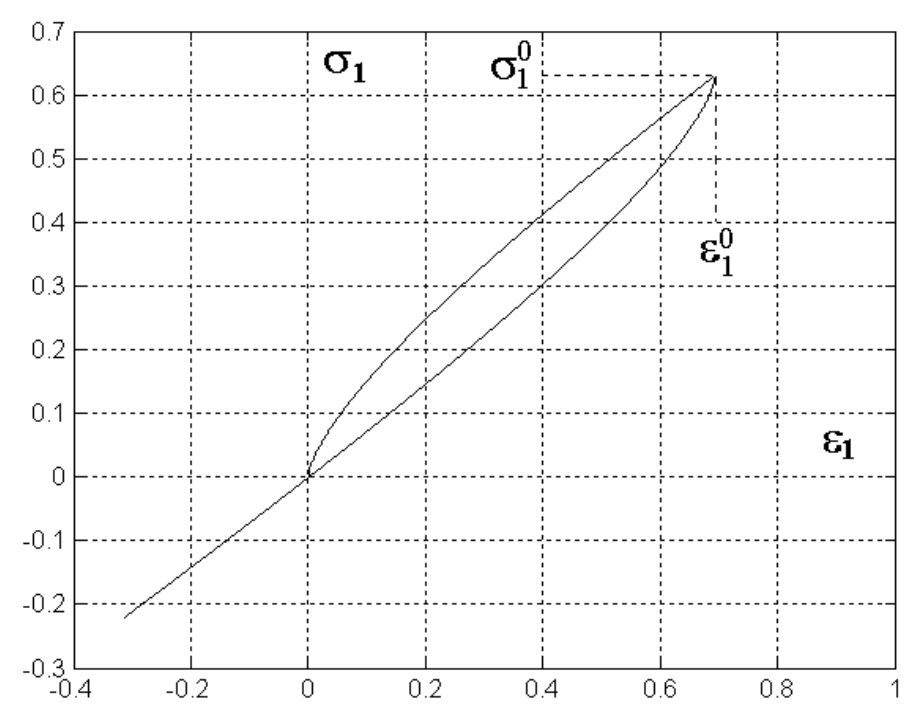

Fig. 4. Uniaxial tension-stress using cycling formulas (11) and (16)

\section{Conclusions}

Thus, the constitutive equations of the new endochronic variant of nonelastic theory in quasi-statistical case are proposed. The equations take into account 
the microstresses and generalize the Sanders's approach. The results of numerical modeling demonstrated the supplementary potentialities in description of nonlinear behavior of materials with initial microstresses. But the results of calculations of uniaxial active and reversible loadings are unexpected. In this regard, the authors plan to perform calculations on the complex loading paths of real materials, to accomplish the special experiments on soils and rocks and to make a final conclusion about the ideas of Sanders.

\section{References}

[1] Sanders J.L.: Plastic stress-strain relations based on linear loading functions. [In:] Proc. U.S. Nat. Cong. of Appl. Mech. (Ann Arbor, MI, 14-18 June 1954), ed. P.M. Naghdi, ASME, New York 1955.

[2] Klyushnikov V.D.: The new conceptions in plasticity and deformation theory. J. Appl. Math. and Mech., 4 (1959), 722-731.

[3] Ilyushin A.A.: Plasticity. Foundations of the general mathematical theory. Akademija Nauk SSSR, Moscow 1963.

[4] Batdorf S.B., Budiansky B.: A mathematical theory of plasticity based on the concept of slip. NASA Technical Note 1871, 1949.

[5] Bazant Z.P.: Endochronic theory inelasticity and incremental plasticity. Int. J. Sol. Struc., 9 (1978), 691-714.

[6] Mroz Z:: A on the description of anisotropic hardening. J. Mech. Phys. Solids, 3 (1967), 163-175.

[7] Kadashevich Yu.I., Novozhilov V.V.: On limit variants of plasticity theory accounting initial microstresses, Mech. Sol., 3 (1980), 93-96.

[8] Valanis K.C.: A theory of viscoplasticity without a yield surface. Part I. General theory. Arch. Mech. Stosow., 4 (1971), 517-534.

[9] Valanis K.C.: A theory of viscoplasticity without a yield surface. Part II. Application to mechanical behavior of metals. Arch. Mech. Stosow., 4 (1971), 535-551.

[10] Kosinski W., Wu H.C.: On steady viscoplastic waves. Endochronic theory, Bull. Pol. Acad. Sci. Techn. Sci., 2 (1978), 109-117.

[11] Kadashevich Yu.I., Mikha'lov A.N.: On theory of plasticity without yield surface. Dokl. Phys., 3/254 (1980), 574-576.

[12] Watanabe O., Atluri S.N.: Constitutive modeling of cyclic plasticity and creep, using an internal time concept. Int. J. Plast., 2 (1986), 107-134.

[13] Kletschkowski T., Schomburg U., Bertram A.: Endochronic viscoplastic material models for filled PTFE. Mech. Mater., 12 (2002), 795-808.

[14] Kadashevich Yu.I., Pomytkin S.P.: On the interconnection of plasticity theory taking into account the microstresses and endochronic theory of plasticity. Mech. Sol., 4 (1997), 99-105.

[15] Valanis K.C.: Fundamental consequence of a new intrinsic time measure-plasticity as a limit of the endochronic theory. Arch. Mech., 2 (1980), 171-191.

\section{Acknowledgement}

The research was supported by grant no 14-01-00202 from Russian Foundation for Basic Researches. 


\section{ENDOCHRONICZNE UOGÓLNIENIE TEORII PLASTYCZNOŚCI SANDERSA}

\section{Streszczenie}

W pracy w ramach podejścia endochronicznego dokonano uogólnienia teorii plastyczności Sandersa i quasi-statystycznego wariantu przyrostowej teorii plastyczności dla izotropowego kinematycznego umocnienia Nowożyłowa. Sformułowano równania konstytutywne endochronicznej teorii zachowania niesprężystego, oparte na koncepcjach Sandersa, Nowożyłowa i Valanisa. Zaproponowano zależności obliczeniowe dla naprężeń i odkształceń w przypadku aktywnego jednoosiowego obciążenia odwracalnego. Zależności te otrzymano przez zastosowanie zasady uśredniania wartości lokalnych dla podstawowego zestawu parametrów materiałowych. W obliczeniach rozważano dwa typy warunków początkowych. Zaprezentowano wyniki obliczeń numerycznych dla materiału niesprężystego poddanego aktywnemu obciążeniu jednoosiowemu oraz obciążeniu okresowemu. Dokonano analizy porównawczej wyników, w tym z wykorzystaniem teorii Sandersa. Przedstawiono różnice i podobieństwa pomiędzy uogólnioną teorią endochroniczną a teorią Sandersa. Wyszczególniono wiele niestandardowych efektów niesprężystego zachowania materiału, wymagających dalszych badań teoretycznych.

Słowa kluczowe: plastyczność, teoria, endochroniczne podejście, równania konstytutywne, wersja quasi-statystyczna

DOI: $10.7862 / \mathrm{rm} .2014 .57$

Otrzymano/received: 14.06.2014 r.

Zaakceptowano/accepted: 20.11.2014 r. 
